DOI: https://doi.org/10.47405/mjssh.v6i3.726

\begin{tabular}{|c|c|}
\hline & Malaysian Journal of Social Sciences and Humanities (MJSSH) \\
\hline 32 & Volume 6, Issue 3, March 2021 \\
\hline 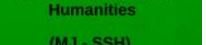 & e-ISSN : 2504-8562 \\
\hline & $\begin{array}{l}\text { Journal home page: } \\
\text { www.msocialsciences.com }\end{array}$ \\
\hline
\end{tabular}

\title{
Validity of Cognitive Behaviour Play Therapy Module (DBPT Module)
}

\author{
Nor Hamizah Ab Razak ${ }^{1}$ Abdul Rashid Abdul Aziz ${ }^{1}$ Mohd Zaliridzal Zakaria1 \\ 1Universiti Sains Islam Malaysia (USIM)
}

Correspondence: Nor Hamizah Ab Razak (norhamizah@usim.edu.my)

\begin{abstract}
Decision making and resilience are the most important element in addressing social and emotional issues among gifted and talented students (GTS). Therefore, Cognitive Behavior Play Therapy Module (CBPT Module) is conceived as an intervention to improve the decision-making skills and resilience among GTS. The purpose of this research is to assess the content validity of this module. The content validity of CBPT Module analyzed by five experts in the field of module construction, gifted students and play therapy. The findings indicated that the coefficient value of the content validity was .92 and based on the sub module and activities was .909. The research proves that CBPT Module has a high content validity hence it is suitable to apply for the GTS that encloses an inadequate and mediate decision-making skills and resilience level.
\end{abstract}

Keywords: gifted and talented student, counselling, play therapy, Cognitive Behavior Play Therapy, module

\section{Introduction}

Gifted and talented students (GTS) have been identified with their special characteristics and they display a differentiated form of capabilities from normal students. Therefore, it is a needed to place them in a special school or institution (Siti Fatimah et al., 2012). There are two GTS institutions in Malaysia, GENIUS@Pintar College and GENIUS Insan College (Abu Yazid, 2015). This research, however, focuses on GTS from GENIUS Insan College where they are Muslim students who are not only academically gifted and but also able to memorize Al- Quran (Abu Yazid\& Noriah, 2016). In the future, these students may become Islamic scholars.

Generally, gifted and talented students are known as individuals who have intellectual excellence, creativity, and a high problem-solving efficiency (Rorlinda et al., 2016). However, at the same time they are also struggling with social and emotional issues initiated from the environmental circumstance and their qualities influence. Domestic and international studies have revealed the cause of social and emotional issues among them is caused by asynchronous developments (Scott, 2012; Abu Yazid\& Aliza, 2009) that bind their lives in cognitive domains, effective, and behavior. Besides that, other factors such as high expectation from various parties, non-challenging and tedious learning and, difficulty in adapting to social interactions also contribute to the problem of socio-emotional issues which can affect the psychological well-being (Abu Yazid \& Noriah, 2010). It is worrying because the social and emotional issues can comminate and impede the development and the competence of GTS which supposedly needs to be mended optimally. In addition, it has a negative effect, such as contributing to the problem of self-motivation, low self-esteem and anxiety. 
The discussion explains that these groups are seen to require special skills and abilities to be applied to address the social and emotional problems faced. Whereas, seeing the decision-making skills that play a role in behavior formation (Zakri \& Saemah, 2015) and resilience that serve as a fortress rather than addressing life's challenges (Chen et al., 2017) makes these two components of GTS extremely demanding. Moreover, both are closely interrelated and affect each other and have proven to solve social and emotional issues such as anxiety and isolation. In contrast, GTS skill and ability studies have not been widely available, although studies on the subject are actively discussed outside the country (Ball et al., 1994; Ersoy \& Deniz, 2016) and also indicate that in the area of decision-making and resilience, these groups need to be improved (Mofield et al., 2016; Ozcan \& Zaaroglu, 2017).

Therefore, Cognitive Behavior Play Therapy Module (CBPT Module) was developed to guide counsellors in giving intervention to GTS in managing their social and emotional issues. As the approach is in line with the development and requirements of GTS, this module is also necessary. This module utilizes a creative approach that focuses on the decision-making skills and resilience of play therapy. The development of this module is also very reasonable as the approach to play therapy is a new approach in Malaysia (Ku Suhaila et al, 2014) and this module can be used as a guide for counsellors in order to improve the decision-making skills and resilience among GTS.

\section{Objectives}

In general, the study is to measure the content validity of CBPT Module. Objectives of this research are (i) to identify the overall content validity of CBPT Module, (ii) to distinguish the content validity of CBPT module on each sub module and activity.

\section{Method}

To identify the content validity of the CBPT module, the study used the survey method. The content validity of CBPT module was determined by the expert evaluation with five experts assigned based on their expertise in the field of module construction, the gifted and talented students and play therapy.

The researcher provided the experts with a complete copy of the CBPT Module and a set of the content validity of the CBPT Module questionnaire to examine, assess and suggest improvements to the content of the module. The data was analyzed descriptively to obtain the percentage value of expert consensus and the content validity coefficient. Module with high content validity will result in achievement in accordance with the objectives that researchers want to measure (Md Noor Saper et al., 2016). According to Tuckman and Waheed (1981) and Sidek and Jamaludin (2005), the achievement of $70 \%$ is considered to attain a high level of content validity obtained based on the following formula;

The experts total score

The overall total score

$$
\mathrm{X} 100 \%=\text { Level of content validity of the module }
$$

\section{Measurement Tools}

This study used a set of content validity questionnaires module based on Russell (1974) views that have been translated and modified by Jamaludin (2002). The questionnaire consisted of five items and use the ten rating points of choice: 1 (strongly disagree) to 10 (strongly agree). Similarly, the content validity questionnaire for sub modules activities using the same scale scoring points and the questionnaire format highlighted by Mohamad Aziz Shah (2010). However, the questionnaire is amended according to CBPT Module requirement consisting of six sub modules; movement therapy, art therapy, clay therapy, sand therapy, music therapy and puppet therapy. 
DOI: https://doi.org/10.47405/mjssh.v6i3.726

\section{The Overall Content Validity of CBPT Module}

Table 1 shows the findings of expert consensus evaluation and it shows the percentage of the lowest content validity is 90 percent for the item of 'The content of this module meets its target population' and 'the contents of this module can be implemented perfectly'. While, the highest percentage of content validity is 96 percent for item 'The content of this module is appropriate to the time allocated'. Hence, the overall score earned for all items is $92 \%$ equal with the content validity coefficient $.92>.70$ and it is shows that this module has a high and good content validity.

Table 1: The overall validity of CBPT Module

\begin{tabular}{|c|c|c|c|c|}
\hline No. & Item & Percentage & $\begin{array}{l}\text { Content } \\
\text { validity } \\
\text { coefficient }\end{array}$ & $\begin{array}{l}\text { Expert } \\
\text { consent }\end{array}$ \\
\hline 1 & $\begin{array}{l}\text { The content of this module meets its target } \\
\text { population }\end{array}$ & $90 \%$ & .90 & Accepted \\
\hline 2 & The content of this module is perfectly executed & $90 \%$ & .90 & Accepted \\
\hline 3 & $\begin{array}{l}\text { The content of this module is appropriate to the time } \\
\text { allocated }\end{array}$ & $96 \%$ & .96 & Accepted \\
\hline 4 & $\begin{array}{l}\text { The content of this module develops the decision- } \\
\text { making skills and resilience }\end{array}$ & $92 \%$ & .92 & Accepted \\
\hline \multirow[t]{2}{*}{5} & $\begin{array}{l}\text { The content of this module affects the decision- } \\
\text { making skills and resilience behavior towards a } \\
\text { more brilliant one }\end{array}$ & $92 \%$ & .92 & Accepted \\
\hline & Total & $92 \%$ & .92 & Accepted \\
\hline
\end{tabular}

\section{Analysis of Sub Modules and Activities Content Validity}

Table 2 displays the content validity for sub modules and its activities. The findings show that the content validity coefficient is 0.909 which also exceeds the minimum value .70. The comparison analysis according to sub modules indicate the value for movement therapy sub module is $.907, .93$ for art therapy sub module, .90 for clay therapy sub module, .91 for sand therapy sub module, .90 for music therapy sub module and .91 for puppet therapy sub module. Next, according to the activities of 'Our Poster' and 'My Expression' share the same validity coefficient value which is .94. While 'Passing Your Love' and 'Ohoo... Snail' record the lowest validity coefficient score which is .88. This confirms that all alpha coefficient value scores are above 0.7 for each activity. This means, the validity of content for activity is high and reliable. In conclusion, the value of CBPT module is based on the assessment experts on each sub module and activity which indicates experts' approval is above the minimum value of .07 in addition to the result that disclose the CBPT Module has a high content validity.

Table 2: The validity of CBPT Module Content Based on Sub Module and Activity

\begin{tabular}{lcc}
\hline Sub Modules and Activities & Percentage & $\begin{array}{c}\text { Validity content } \\
\text { coefficient }\end{array}$ \\
\hline MOVEMENT THERAPY SUB & $\mathbf{9 0 . 7 \%}$ & $\mathbf{. 9 0 7}$ \\
MODULE & $90 \%$ & .90 \\
Activity 1: Chan Mali Chan & $88 \%$ & .88 \\
Activity 2: Passing Your Love & $94 \%$ & .94 \\
Activity 3: Our Poster & & \\
ART THERAPY SUB MODULE & $\mathbf{9 3 \%}$ & $\mathbf{. 9 3}$ \\
Activity 4: My Expression & $94 \%$ & .94 \\
Activity 5: Window of My Heart & $92 \%$ & .92 \\
CLAY THERAPY SUB MODULE & $\mathbf{9 0 \%}$ & .90 \\
Activity 6: My Dreaming World & $90 \%$ & .90 \\
Activity 7: Who's the Winner?? & $90 \%$ & .90 \\
\hline
\end{tabular}


DOI: https://doi.org/10.47405/mjssh.v6i3.726

\begin{tabular}{lll}
\hline Activity 8: Ohoo..Snail & $88 \%$ & .88 \\
SAND THERAPY SUB MODULE & $\mathbf{9 1 \%}$ & $\mathbf{. 9 1}$ \\
Activity 9: Nice to Meet You & $92 \%$ & .92 \\
Activity 10: The Beauty of Relationship & $90 \%$ & .90 \\
MUSIC THERAPY SUB MODULE & $\mathbf{9 0 \%}$ & $\mathbf{. 9 0}$ \\
Activity 11: Melodious... & $90 \%$ & .90 \\
Activity 12: Love \& Lover & $90 \%$ & .90 \\
PUPPET THERAPY SUB MODULE & $\mathbf{9 1 \%}$ & $\mathbf{9 1}$ \\
Activity 13: Puppet World & $90 \%$ & .90 \\
Activity 14: Bonding & $92 \%$ & .92 \\
\hline
\end{tabular}

\section{Discussion}

The theory of CBPT is one of the most appropriate theories to be used as a framework for develop the CBPT Module, as it highlights the aspects of thinking and beliefs that affect the behavior that is accurately applied to GTS which often have social and emotional problems. In addition, the approach of play therapy itself is loaded with creative elements. Subsequently, understanding that GTS has the cognitive and creative qualities used the inclined fantasy to provide a safe distance from the real-world challenges that carry all the problems encountered. Furthermore, CBPT is also a structured and directive formed theory that makes it suitable as a framework module.

This study also found that there is a high content validity value for the CBPT module, sub module and activity. The results therefore indicate that the CBPT Module can be used and tested for its efficacy in the GTS population. The development of this module contributes to the improvement of GTS life, regarded as privileged students. This module can also enhance the knowledge and skills of counsellors on play therapy that can be effectively applied to these unique and gifted group such as GTS thereby contributing in the field of counselling, especially guidance and counselling services.

In the meantime, the CBPT Module can be distributed as a guide for counsellors to improve GTS decision-making and resilience skills, effectively addressing social and emotional problems as follows. In view of the fact that the study on play therapy in Malaysia is quite limited, this study is expected to be one of the reference sources in the field of play therapy and to help counselors to diversify counselling strategies and techniques that can be used for various client problems in the counselling process.

It can therefore be concluded that CBPT Module can be developed and applied in further experimental studies. With this, it is appropriate to carry out further studies to test the effectiveness of the CBPT Module in the context of GTS in GENIUS Insan College.

\section{References}

Abu Yazid, A. B. \& Noriah, M.I. (2010). Counselling Issues of Gifted Students Attending a School Holiday Residential Program: A Malaysian Experience. Procedia - Social and Behavioral Sciences, 7(C), 568-573.

Abu Yazid, A. B. \& Noriah, M.I. (2016). Pendidikan pintar dan berbakat di Malaysia, Bangi, UKM.

Abu Yazid, A.B. (2015). Counseling Malaysian Gifted Students: How Can It Be Done? 10.13140/RG.2.1.2027.9845.

Abu Yazid, A.B. \& Aliza, A. (2009). Sokongan psikologikal dan sosio-emosi pelajar pintar cerdas. In Noriah M.I., Rosadah A.M. \& Siti Fatimah M.Y. (Eds.), PERMATApintar: Pengalaman UKM. Bangi: UKM.

Ball, C., Mann, L. \& Stamm, C. (1994). Decision-Making Abilities of Intellectually Gifted, Australian Journal of Psychology, 46(1), 13-20.

Chen, X., Cheung, H. Y., Fan, X. \& Wu, J. (2017). Factors Related to Resilience of Academically Gifted Students in The Chinese Cultural and Educational Environment. Psychology in the 
Schools, (January), 1-13.

Ersoy, E. \& Deniz, M. E. (2016). Psychometric Properties of the Gifted Students' Coping with Anger and Decision Making Skills Scale. Journal of Education and Practice, 7(15), 121-128.

Jamaludin Ahmad (2002). Kesahan, Kebolehpercayaan dan Keberkesanan Modul Program Maju Diri ke atas Motivasi Pencapaian di Kalangan Pelajar Sekolah Menengah Negeri Selangor. Tesis Doktor Falsafah yang tidak diterbitkan. Universiti Putra Malaysia, Serdang Selangor.

Ku Suhaila Ku Johari, Mary Alice Bruce \& Mohamad Isa Amat. (2014). The Effectiveness of ChildCentered Play Therapy Training in Malaysia. Asian Social Science, 10:7.

Mofield, E., Parker Peters, M. \& Chakraborti-Ghosh, S. (2016). Perfectionism, Coping, and Underachievement in Gifted Adolescents: Avoidance vs. Approach Orientations. Education Sciences, 6(3), 21.

Md Noor Saper, Nurul Ain Mohd Daud \& Norazani Ahmad. (2016). Kesahan dan Kebolehpercayaan Modul I-Sc ke atas Pelajar Bermasalah Tingkah laku. International Journal of Islamic Thought, $9(6), 32-43$.

Ozcan, D., Zaaroglu, L. (2017). Determination of The Relationship Between Strategies of DecisionMaking And Emotional Intelligence Of Gifted Students. ENSAYOS, 32(2).

Rorlinda, Y., Noriah, M.I., Siti Aishah. H \& Afifah. M.R. (2016). Kajian Jati Diri dan Tekanan Isu Sosio-Emosi dalam Kalangan Pelajar Pintar dan Berbakat. Jurnal Psikologi Malaysia, 30(2), $42-60$.

Russell, J.D. (1974). Modular Instruction: A Guide to the Design, Selection, Utilization and Evaluation of Modular Materials. New York: Publishing Company.

Siti Fatimah, Y., Noriah, M.I., Melor, M.Y. \& Rosadah, A. M. (2012). The Identification of Gifted and Talented Students. Procedia - Social and Behavioral Sciences, 55(2005), 585-593.

Sidek Mohd Noah \& Jamaludin Ahmad (2005). Pembinaan modul: Bagaimana membina modul latihan dan modul akademik. Serdang: Universiti Putra Malaysia

Tuckman, B.W. \& Waheed, M.A, (1981). Evaluating and Individualized Science Programme for Community College Students. Journal of Research in Science Teaching, 18: 489 - 495.

Zakri Abdullah, Saemah Rahman. (2015). Kemahiran Meta-Tingkah Laku dan Kemahiran Membuat Keputusan Pelajar Bermasalah Disiplin dan Tidak Bermasalah Disiplin. Jurnal Pendidikan Malaysia. 